DOI: 10.31392/NPU-nc.series14.2019.27.12

УДК $7.71 .5-05$

3iзa 0.

\title{
Формування музичного мислення майбутніх учителів музичного мистецтва в ході застосування компетентнісного підходу
}

\begin{abstract}
У статті досліджуються особливості реалізації компетентнісного підходу до формування мисленнєвої діяльності майбутніх учителів музичного мистецтва у процесі музичного навчання загалом та під час удосконалення музично-інтонаційного словника. Компетенцію ми розуміємо як сукупність взаємопов'язаних якостей особистості, сукупність знань, умінь, навичок та способів діяльності. Також виокремлюємо поняття компетентність як володіння людиною відповідною компетенцією, що містить іiі особистісне ставлення до предмета діяльності. Компетентнісний підхід в освіті пов'язаний з особистісноорієнтованим і діяльнісним підходами до навчання, оскільки грунтується на особистості індивіда та може бути реалізованим і перевіреним тільки в процесі виконання певного комплексу дій. Об'єм музичного мислення розглядається нами з точки зору розвиненості музично-інтонаційного словника майбутніх учителів, удосконалення якого створює основу для формування здібності поєднувати окремі музичні враження в цілісну картину музичного мистецтва, і творчого прояву учителя в музиці. Мислення як процес пізнання предметів або явищ включає пошук зв'язків: зовнішніх і внутрішніх, істотних i неістотних. У музичному мистецтві особливо важливий зв'язок явищ у русі, мінливості в співвідношенні звучних елементів. Інтонаційний словник розуміємо як “запас” музичних інтонацій, котрі сподобалися і запам'яталися.
\end{abstract}

Ключові слова: компетентнісний підхід; компетентність; компетенція; музичне мислення; музичноінтонаційний словник.

Реалізація культуротворчої функції в освіті детермінована необхідністю підвищення загальної культури суспільства й утвердження в педагогічному середовищі парадигми особистісно-орієнтованої освіти.

У сьогоденних умовах трансформаційних зрушень у всіх сферах української держави професійна підготовка майбутнього фахівця постає провідним чинником іiі соціального й економічного прогресу.

Перехід від авторитарної освіти до гуманістичної педагогіки співробітництва, що розпочався у сучасному вітчизняному навчанні, висуває нові вимоги до підготовки випускників закладів вищої освіти, серед яких - необхідність формувати людину компетентну, тобто здатну до активної участі в суспільному житті, до самореалізації та постійного самовдосконалення. Так як компетентність особистості стає вирішальною умовою та показником успішності людини в житті загалом, то виникає потреба у такій підготовці і у закладах вищої освіти, які впливають на професійну діяльність зокрема.

Поняття "компетенція" та “компетентність" для української педагогіки $є$ відносно новими, тому зустрічаються різні їх тлумачення. У професійній педагогіці також немає одностайного підходу до розуміння компетентнісного підходу і шляхів його впровадження в освітню діяльність, тому ця проблема є предметом подальших перспективних дискусій i досліджень.

Здебільшого компетенцію розуміють як сукупність взаємопов'язаних якостей особистості, сукупність знань, умінь, навичок та способів діяльності. Але поряд із цим поняттям виокремлюють і компетентність як володіння людиною відповідною компетенцією, що містить ії особистісне ставлення до предмета діяльності. Компетентнісний підхід в освіті пов'язаний 3 особистісно-орієнтованим і діяльнісним підходами до навчання, оскільки грунтується на особистості учителя та може бути реалізованим і перевіреним тільки в процесі виконання конкретним майбутнім учителем певного комплексу дій. Він потребує трансформації змісту освіти, перетворення його з моделі, яка існує об'єктивно, для "усіх" учитлів, на суб'єктивні надбання одного учителя, які можна виміряти. Компетентнісний підхід акцентує увагу на результатах освіти, причому як результат освіти розглядається не сума засвоєної інформації, а здатність людини діяти у різних проблемних ситуаціях. 
Проблема вдосконалення системи освіти шляхом упровадження компетентнісного підходу активно обговорюється у педагогічній науці. Розв'язання окресленої проблеми започатковане у працях Дж. Равена, А. Л. Андреєва, І. О. Зимньої, А. В. Хуторського, Г. Селевка, О. І. Пометун, Р. Пастушенка, О. В. Овчарук та інших вітчизняних і закордонних дидактів [7, с. 13].

Проблемі компетентнісної освіти у своїх працях приділяли увагу такі українські науковці, як I. Бех, Л. Масол, І. Зязюн І. Єрмаков, О. Олексюк, О. Овчарук, О. Щолокова та багато інших. Розрізняють компетентності загальні та предметні; у більшості своїх наукових розвідок обгрунтовують бачення цієї категорії як інструмента вирішення типових i нестандартних ситуацій, як здатності людини бути активною в найрізноманітніших життєвих ситуаціях.

I. Зязюн охарактеризовує компетентність як здатність вирішувати професійні завдання певного класу, що вимагає наявності реальних знань, умінь, навичок і досвіду. Вони мають вияв у практиці професійної діяльності як системна характеристика, із чітко визначеною структурою. Компетентність може набувати кількісного виміру, зокрема шляхом виокремлення рівнів. Аналогічним є шлях визначення якості - соціальної, методологічної, технологічної й ін.

Видатний вчений Г. Халаш стверджує, що компетентність охоплює широкий спектр соціальних, комунікативних умінь, підгрунтям яких виступають знання та досвід, цінності, сформовані у процесі навчання. Він підкреслював, що компетентність - це реальна здатність застосувати знання.

Впровадження компетентнісного підходу у музичну освіту передбачає підготовку спеціалістів нової формації, що не лише володіють знаннями та уміннями музикування, а здатні аналізувати художньо-соціальні явища, застосовувати мистецтво, зокрема музику, для духовного розвитку.

Мета статті полягає в обгрунтуванні актуальності компетентнісного підходу до формування музичного мислення у майбутніх учителів музичного мистецтва у процесі музичного навчання.

Передусім, зазначимо, що мислення - це особлива ідеальна діяльність людини, яка виникає, формується, розвивається в суспільстві, коли людина перебуває у певному соціокультурному середовищі і вступає в багатогранні відносини з природним і соціальним світом, що іï оточує. На сучасному етапі мислення людини є об'єктом дослідження багатьох наук: психології, соціології, логіки, теорії штучного інтелекту та ін.

Відомо, що основними функціями мислення є: пізнавальна (відображення світу і самовідображення); проектувальна (побудова планів, проектів, моделей практичної i теоретико-пізнавальної діяльності); прогнозна (прогнозування або передбачення наслідків своїх дій, своєї діяльності, прогнозування майбутнього); інформаційна (засвоєння інформації про знання та іï смислове перероблення); технологічна (розроблення правил, норм, стандартів, рецептів життєдіяльності людини і суспільства в різних формах та проявах); рефлексивна (самопізнання розуму, самоаналіз); інтерпретаторська (тлумачення, осмислення продуктів людської культури) тощо.

Проблема формування музичного мислення $\epsilon$ одним із актуальних питань в музикознавстві, музичній педагогіці і психології. У музикознавстві вже є спроби створити цілісну концепцію музичного мислення на основі вживання ідей сучасної психології, естетики, лінгвістики, теорії інформації, кібернетики і так далі. Але найбільш ефективним, на наш погляд, є підхід до музичного мислення з боку суто музики [4].

Специфіка музичного мислення в творчості, виконанні, сприйнятті спонукає нас глибше проникати в природу музичного мистецтва і саме там шукати відповіді, які необхідні сьогодні музичній педагогіці.

Суть музичного мистецтва полягає не в конкретиці зображення яких-небудь картин або явищ, а в узагальненому вираженні в музиці відчуттів, думок, ідей. Щоб найбільш 
узагальненим чином підійти до проблеми музичного мислення, спробуємо порівняти іï із стрижневими сторонами мислення. Крім того, закони мислення в музиці, безумовно, співвідносяться із загальними законами і принципами мислення взагалі.

У філософському аспекті на особливу увагу заслуговують три основні функції мислення: пізнання істотних зв'язків і відношення предметів та явищ, творче створення нових ідей, здібність до виокремлення, утримання і оперування всім об'ємом понять, образів [6]. 3 психологічної точки зору мислення - це цілеспрямоване використання, розвиток i накопичення знань.

Ці трактування не суперечать один одному, а багато в чому збігаються і доповнюють один одного, тому що в кожному 3 філософських аспектів присутні психологічні і навпаки. Аналіз різних підходів до вивчення мислення привів нас до виділення трьох найважливіших аспектів розвитку музичного мислення майбутніх учителів: це об'єм, зв'язок і творчість.

Розглянемо загальні музичні основи цих трьох аспектів і специфіку їх формування під час музичних занять з окремо взятим студентом, використовуючи при цьому компетентнісний підхід до навчання музики.

Розвинене мислення людини характеризується здатністю утворення змістовних абстракцій, що допомагають відтворювати цілісність явища, процесу або предмету. Психологи давно наполягають на можливо ранньому розвитку у школярів здібностей до утворення змістовних узагальнень, які виокремлюють такі сторони, властивості і стани предмету, які вже володіють самостійністю. Це дозволяє в стислому вигляді охоплювати різноманіття предметів, зводити їх в певні класи, які є самостійними.

Що може виконувати роль змістовної абстракції, яка володіє певною самостійністю і цілісністю, і яка дозволяє здійснювати вищеописані розумові операції в музичному мистецтві? Відповідь одна - інтонація. Але не в звичному розумінні музикантів - чиста або нечиста, а в підході до інтонації як до сенсу. Такий підхід був розроблений Б. В. Асаф'євим в його інтонаційній теорії. У цій теорії під інтонацією, в широкому плані, розуміється зміст промови, ії психічний тонус, настроєвість. У вужчому - “фрагменти музики”, “мелодійне утворення”, “пам’ятні миті”, “зерна-інтонації” [3].

Об'єм музичного мислення пропонуємо розглядати з точки зору розвиненості музичноінтонаційного словника студентів, удосконалення якого створює основу для формування здібності поєднувати окремі музичні враження в цілісну картину музичного мистецтва, i творчого прояву студента в музиці. Дійсно, якщо в майбутнього учителя музичного мистецтва немає “слів” (“фрагментів музики”) в його інтонаційному словнику, то, звичайно, він не може стежити за появою в творі нових інтонацій, порівнювати їх і так далі Тому завдання педагога полягає в тому, щоб накопичувати, поглиблювати інтонаційний словник музиканта, а, особливо, формувати і закріплювати в особистісному досвіді студента “пам'ятні миті" з класичних творів. Саме такі форми роботи над розвитком мисленнєвої діяльності студентів мистецьких закладів вищої освіти, які спрямовані на формування музичної компетенції загалом, видаються нам дуже актуальними і необхідними.

Акцент на класичній музиці зроблений не випадково. Досвід роботи багатьох педагогів за останні роки показує, що для майбутніх учителів результативним є використання на заняттях таких класичних творів, як: “Бабак” Л. Бетховена, “Арія Сусаніна" М. Глінки, 3 частина 5 симфонії Л. Бетховена, "Вальс" 3 балету "Спляча красуня" П. Чайковського, "Ранок" Е. Гріга і ін., які можуть стати улюбленими для студентів. А от для молодших студентів, майбутніх учителів музичного мистецтва, цікавими будуть такі класичні шедеври: "Престо" Дж. Пішетті, “Баркарола” П. Чайковського, А. Валь “Арія”, “Сонатіна” Л. Бетховена, “Марш Чорномора” М. Глінки, вступ до опери “Запорожець за Дунаєм” А. Гулака-Артемовського, “Угорський танець № 5" Й. Брамса, вступ до опери "Кармен” Бізе, 9 симфонія Л. Бетховена тощо. На жаль, поки на заняттях частіше домінують п’єси, які переважно мають або ідеологічний, або моралізаторський, або розважальний характер. Здобуваючи музичну освіту у мистецьких навчальних закладах, студенти мають можливість систематично ознайомитися 3 
музичними шедеврами. Слід зауважити, що під інтонаційним словником ми розуміємо не словник музичних термінів, а “запас" музичних інтонацій, які сподобалися, запам'яталися майбутнім учителям.

Мислення як процес пізнання предметів або явищ завжди включає пошук зв'язків: зовнішніх і внутрішніх, істотних і неістотних. У музичному мистецтві особливо важливий зв'язок явищ у русі, мінливості в співвідношенні звучних елементів. Основою для спостереження цих взаємозв'язків може стати інтонація. Усередині твору одна інтонація викликає іншу, пов'язується 3 нею. В цілому, інтонація в музичному мистецтві стає тією ланкою, яка поєднує воєдино всі сторони музичної культури: і факти творчі, і стильові, й еволюцію виразних елементів, i формоутворення. Явище інтонації пов'язує музичну творчість, виконання і процес “слухати - почути”. У масовій музичній педагогіці сьогодні мало розроблених методів роботи, спрямованих на встановлення інтонаційних взаємозв’язків між музичними творами, що вивчаються на заняттях, творчістю певного композитора, стилями, жанрами.

Висновки. Недостатнє обгрунтування подібних методів не дозволяє майбутнім учителям музичного мистецтва, сприймати кожен новий твір цілісно, “бачити” зв’язки нового твору 3 уже відомими, вивченим, який $\epsilon$ подібним за будовою, стильовими $\mathrm{i}$ жанровими особливостями музики. А такий регресивний процес гальмує формування цілісного уявлення про музичне мистецтво, як базу повноцінної музичної творчості майбутнього учителя. Крім того, занепадає ефективне формування мисленнєвої діяльності окремо взятого студента, адже порушується удосконалення логіко-музичних зв'язків. Таким чином, можемо зробити висновок, що компетентнісний підхід до формування музичного мислення у майбутніх учителів музичного мистецтва у процесі музичного навчання $є$ важливим етапом для поглиблення музичної освіченості загалом.

\section{Література}

1. Апатский В. Н. История духового музыкально-исполнительского искусства / В. Н. Апатский. - К. : ТОВ «Задруга», 2010. -320 с.

2. Апатский В. Н. Основы теории и методики музикально-исполнительского искусства: Учеб. пособие / В. Н. Апатский. - К. : НМАУ ім. П.І. Чайковського, 2006. - 432 с.

3. Асафьев Б. В. Русская музыка ХІХ и начала ХХ века / Б. В. Асафьев. - Л. : Музыка, 1968. C. $111-131$.

4. Апраксина О. А. Музыкальное воспитание в школе / О. А. Апраксина. - Москва, 1999.

5. Белобородова В. К. Музыкальное восприятие к теории вопроса. Музыкальное восприятие школьников / В. К. Белобородова. - Москва, 2000.

6. Дмитриева Л. Г. Методика музыкального воспитания в школе / Л. Г. Дмитриева, Н. М. Черноиваненко. - Москва, 2000.

7. Лігоцький А. О. Система різнорівневої підготовки фахівців в Україні (теоретикометодологічний аспект) : автореф. дис... д.пед.наук : 13.00.04 / А. О. Лігоцький. - К., 1997. - 36 с.

8. Михайлова М. А. Развитие музыкальных способностей детей / М. А. Михайлова. - Ярославль : Академия развития, 2003.

9. Холопова В. Н. Проблемы музыкального ритма / В. Н. Холопова. Москва, 2003.

10. Цюлюпа Н. Л. Педагогічні умови формування методичної компетентності майбутнього вчителя музики в процесі інструментальної підготовки [Текст] : автореф. дис... канд. пед. наук: 13.00.02 / Цюлюпа Наталія Леонідівна ; Національний педагогічний ун-т ім. М.П.Драгоманова. - К., 2009. $-20 \mathrm{c}$.

Про автора:

Зіза Олександр, аспірант кафедри мистецьких дисциплін та методик їх викладання Кременецької обласної гуманітарно-педагогічної академії ім. Тараса Шевченка (47003, Кременець, Україна); ORCID: 0000-0001-6779-0922 


\section{Formation of musical thinking of future music teachers in the course of applying competency-based approach}

The article explores the peculiarities of the implementation of a competency-based approach to the formation of the thinking activity of future music teachers in the process of music education in general and during the improvement of the musical-intonational vocabulary. We understand competence as a set of interrelated personality traits, a set of knowledge, skills, abilities, and practices. We also give emphasis to the concept of competence as the possession of a person's relevant competence, which contains his or her personal attitude to the object of activity. A competency-based approach to education is linked to a personcentered and activity-based approach to learning, as it is based on the individual's personality and can only be implemented and tested in the course of performing a set of actions.

We consider the volume of musical thinking in terms of the development of the music-intonation vocabulary of future teachers, whose refinement creates the basis for forming the ability to combine individual musical impressions into a holistic picture of musical art, and the creative expression of the teacher in music.

Thinking as a process of knowing objects or phenomena involves searching for connections: external and internal, essential and insignificant. In the art of music, the connection of phenomena in motion, variability in the ratio of sound elements is especially important.

In the article, we identify the intonation dictionary not as a dictionary of musical terms, but as a "stock" of liked musical intonations was remembered.

It needs to transform the content of education, to transform it from a model that exists objectively, for "all" teachers, to the subjective attributes of one teacher who can be measured. The competency-based approach focuses on the results of education, and the result of education is not the amount of information learned, but the ability of a person to act in various problematic situations.

Keywords: competency-based approach; competency; competence; musical thinking; music-intonation dictionary.

\section{References}

1. Apatskij V. (2010). History of wind musical performing art. Kyiv: TOV Zadruga [in Ukrainian].

2. Apatskij V. (2006). Fundamentals of the theory and methodology of performing arts. Kyiv: NMAU im. P.I. Chajkovskogo [in Ukrainian].

3. Asafev B. (1968). Russian music of the 19th and early 20th centuries. Leningrad: Muzyka [in Russian].

4. Apraksina O. (1999). Musical education at school. Moscow: Muzyka [in Russian].

5. Beloborodova V. (2000). Musical perception to the theory of a question. Musical perception of schoolchildren. Moscow: Muzyka [in Russian].

6. Dmitrieva L. (2000). Methods of music education at school. Moscow: Muzyka [in Russian].

7. Ligockij A. (1997). The system of technical training in Ukraine (theoretical and methodological aspect). Kyiv: IZMN [in Ukrainian].

8. Mihajlova M. (2003). The development of musical abilities of children. Yaroslavl: Akademiya razvitiya [in Russian].

9. Holopova V. (2003). Music rhythm problems. Moscow: Muzyka [in Russian].

10. Cyulyupa N. (2009). Pedagogical conditions for forming methodological competence of future music teacher in the process of instrumental preparation. Kyiv: Nacionalnij pedagogichnij un-t im. M.P. Dragomanova [in Ukrainian].

\section{About the author:}

Ziza Oleksandr, postgraduate student, Kremenets Regional Humanities and Pedagogical Academy named by Taras Shevchenko (47003, Kremenets, Ukraine); ORCID: 0000-0001-6779-0922 